\title{
Internet resources for the 1996 election
}

\author{
By the ACRL Law and Political Science Section Library Instruction Committee
}

\section{Extra! Extra! Get all your election information bere!}

- olitical Campaigning in Cyberspace: Selecting Leaders for the Future" was the theme of an exciting program sponsored by ACRL's Law and Political Science Section at the 1996 ALA Annual Conference. To support the program, the section's Library Instruction Committee prepared a Web page devoted to Internet campaign resources called "Campaigning in Cyberspace: Parties, Candidates, Issues and Analysis" (http://refserver.lib.vt.edu/stemmer/ cyberpolitics.html). Committee members worked on one or more sections of the page, screening, selecting, and often annotating sites dealing with political parties, primaries, conventions, presidential candidates, issues, state and local candidates, nonpartisan groups, news analysis, scholarly discussion lists, and electronic conferences. This column is based on the resources selected by committee members.

\section{National political parties}

The Information Superhighway allows interested groups to promote their ideas and points of view easily and quickly. Political parties have been quick to take advantage of this new way to disseminate information on their candidates and recruit new members and volunteers. Smaller political parties, in particular, have found that the Internet can greatly expand the reach of their organizations.

- Communist Party USA. Party information, position papers, and selected articles from the People's Weekly World are included at this site. Access: http://www.hartford-hwp.com/cpusa/.

- Democratic Party Online. This official site has news and features from the party, convention updates, briefings, press releases, and news from the White House. Read the NewtGram, a newsletter published by the Democratic National Committee that "chronicles the exploits" of House Speaker Gingrich. $A C$ cess: http://www democrats.org.

- Green Party. Research the party's history and platform, review past election results, and read organizing and campaign tips. Access: http://www.greens.org/usa/.

- Libertarian Party. This site offers the party's position papers and publications explaining the party's history and goals, as well as information on upcoming elections. Access: http: //www.lp.org/lp/lp.html.

- Natural Law Party. This page seeks to further the party's emphasis on "proven solutions for America through prevention-oriented government" by providing information about the party's history, stance on the issues, and platform. Listen to audio clips from the party's candidates. Access: http://www.natural-law.org/ nlpusa/.

- Reform Party. This page includes press releases, news articles, and state-by-state eleclion information. Access: http://www reformparty.org/.

- Republican National Committee (RNC). Organized around the concept of a small town main street, this site includes the party platform, rules and other information about the RNC (at H.Q.), news releases (at the newsstand), position statements, charts and graphs (in the school), and GOP contact information (in the

Members of the ACRL Law and Political Science Section Library Instruction Committee are Laura Bartolo (chair), Christine Angolia, Elaine Coppola, Janice Steed Lewis, Jobn Stemmer, Lisa Stimatz, and Sally Willson Weimer. 
post office). Order GOP golf shirts and coffee mugs in the gift shop. Access: http://www.rnc. org/

- Socialist Party USA Cybercenter. The Cybercenter includes the party's principles and history, an online discussion list, and information on how to join. Access: http://sunsite.unc. edu/spc/index.html.

- National Politics \& Personalities. An extensive list of links to mainstream and fringe political organizations, both liberal and conservative. Access: http://www.rtis.com/nat/ $\mathrm{pol} /$.

- Third Party Central. Provides information on the third party movement in American politics in order to raise public awareness of these alternative parties and to encourage participation in the democratic process. Access: http: //www. math.princeton.edu/ $\sim$ tpbarber/3pc.

\section{Democratic Party candidates}

Note: Only candidates who were still in the presidential race in June 1996 are included here. The information was current as of August 12.

\section{Bill Clinton}

- Clinton/Gore '96. Funded by the Clinton/ Gore Primary Committee, this site was unveiled in July. The administration's accomplishments, campaign issues, and biographies of the candidates are included. "Downloadables" lets surfers download campaign buttons and video clips. Access: www.cg96.org

- The President of the United States. A de facto campaign site, with recent presidential accomplishments, Clinton's biography, photographs, and the text of his public addresses. Access: http://www.whitehouse.gov/.

- Clinton, Yes! Unofficial homepage with news articles and excerpts from speeches. $A C$ cess: http://www.av.qnet.com/ -yes/.

- Clinton/Gore '96. Humorous yet friendly unofficial campaign site, heavy on images, with links to other Clinton/Gore and Democratic sites. Access: http://www.linknet. net/ lsufan/politics.htm.

\section{Lyndon LaRouche}

- LaRouche Exploratory Committee. Official campaign headquarters, with biographical information and issue areas. Access: http:// www.clark net/larouche/welcome.html.

\section{Republican Party candidates}

\section{Pat Buchanan}

- Pat Buchanan's Official Internet Campaign Headquarters. This official campaign page includes articles and essays by Buchanan, his position statements, and biography. The site can be searched by keyword. Access: http:/ www.buchanan.org/.

- The Pat Buchanan for President Link. This unofficial site has a comprehensive collection of Buchanan material, including sound clips. Access: http://www,iac.net/ davcam/ pat.html.

- Pat Buchanan's Republican Primary Page. Buchanan's announcement speech, biography, positions on the issues, speeches, and press coverage can be found at this site. Access: http://www.umr.edu:80/ sears/primary/ buchanan.html.

\section{Bob Dole}

- Official Dole for President Homepage. This comprehensive, user-friendly site has many interactive features including a U.S. map that tracks the Dole campaign's progress in every state. The library includes press releases, fact sheets, speeches, sound clips, videos, and photographs. Access: http://www.dole96.com/.

- Bob Dole's Republican Primary Page. Campaign finance information, Dole's voting record, ratings by special-interest groups, speeches, and a biography can be found at this site. Access: http://www.umr.edu/ $\sim$ sears/primary/dole.html.

- The Bob Dole Supplement. In addition to the usual speeches, news articles, and quotes, this site includes trivia questions, commentary, and the ability to search Usenet posts. It also includes some Spanish-language articles. Access: http://www.seas.upenn.edu/ lapple/ bobdole.html.

\section{Robert K. Dornan}

- Bob Dornan's Republican Primary Page. This unofficial site includes Dornan's biography, voting record, ratings by specialinterest groups, and campaign finance information. Access: http://www.umr.edu:80/ sears/ primary/dornan.html.

\section{Alan Keyes}

- Alan Keyes for President '96. This unofficial page from the Right Side of the Web 
LIBRARIES: RESERVE YOUR SAMPLE COPY TODAY!

Gain valuable expert knowledge about organizing

and cataloging Internet resources!

\section{JOURNAL OF}

INTERNET CATALOGING

\section{THE INTERNATIONAL QUARTERLY OF \\ DIGITAL ORGANIZATION. CLASSIFICATION \& ACCESS}

\section{Co-Editors:}

RUTH C. CARTER, PhD, MA, MS

Assistant Director for Automated and Technical Services, University of Pittsburgh Libraries

\section{ROGER BRISSON}

The Pennsylvania State University Libraries

A convenient guide for experts in cataloging, the exciting new Journal of Internet Cataloging features articles on current developments in the area of cataloging Internet resources and pulls together-in one place-theoretical and practical aspects related to cataloging and organizing digital resources available via the Internet. You will benefit from the efforts made by early researchers in the field and see what works and what doesn't. Read about:

- Web sites

a the use of classification and automated assists for organizing Web resources

a software and hardware for retrieving, reviewing, and describing Internet resources

a various philosophical topics

a management of the cataloging process of Internet resources

- descriptive and subject cataloging applied to Internet resources

- up-to-date descriptions of projects for organizing or cataloging Internet resources

- problems in maintaining catalog records for remote electronic resources

- cooperative projects and international aspects and issues in organizing/cataloging Internet resources

The Haworth Press, inc

10 Alice Street

Binghamton, NY 13904-1580 USA
This is the only journal devoted exclusively to cataloging, organization, and provision of access to Internet resources rather than on retrieval is. sues. The journal also provides the convenience and stability of print to archiving information about this rapidly developing field.

Gain valuable, diverse perspectives from the heavy international component to the Journal reflected in the international makeup of the Editorial Board.

Any library professional or systems personnel working with the Internet will find the innovative Journal of Internet Cataloging essential for keeping an edge in this age of rapidly evolving and unpredietably changing technology.

\begin{tabular}{l}
\hline A SNEAK PRFVIFW... \\
The New/Old World Web Order: The \\
Application of 'Neo-Conventional' Function- \\
ality to Facilitate Access and Use of a WWW \\
Database of Science and Technology Internet \\
Resources - Cataloging Internet Resources: \\
A Practitioner's Guide - Cataloging Internet \\
Resources: An Administrator's Viewpoint - \\
Cataloging Internet Accessible Chinese \\
Electronic Journals - To Catalog or Not to \\
Catalog Internet Resources - Citations for the \\
Networked Document - Yahoo! Cataloging \\
the Web - more!
\end{tabular}

VISIT THE JOURNAL'S WEB PAGE AT

hltp://www.libraries.psu.edu/iasweb/personal/rob/ic.htm

Volume 1, No. 1-Spring 1997. Quarterly (4 issues). Subscription rates (per volume):

Individuals: \$35/ Institutions: \$65/ Libraries: $\$ 65$

SPECIAL SAVINGS FOR MULTIPLE VOLUME PURCHASES: Save $10 \%$ on your 1-volume subseription! Save $20 \%$ on your 2 -volume subscription! Save $30 \%$ on your 3-volume subscription! (Sorry, offer not good to libraries)

PAD96 CALL: 1-800-HAWORTH • FAX: 1-800-895-0582 • E-MAIL: GETINFO@HAWORTH.COM 
includes a letter from Keyes, the text and audio of speeches, and Keyes's biography. Access: http://www.clark.net/pub/jeffd/keyes_96. html.

- Alan Keyes Network Home Page. Comprehensive campaign information, including press releases, positions on issues, and speeches can be found at this unofficial page, along with campaign paraphernalia ranging from brochures to t-shirts. It also includes browsable archives of mailing list messages and quotations by Keyes. Access: http://sandh.com/keyes/index. html.

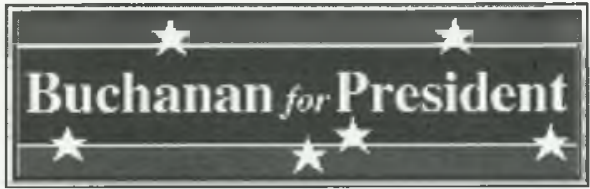

\section{Green Party candidate \\ Ralpb Nader}

- The Unofficial Ralph Nader for President Page. This page includes interviews, press coverage, and links to organizations founded by Nader. Access: http://www.rahul.net/ cameron/nader/.

- Draft Nader for President Clearinghouse. This unofficial page includes information on how to assist Nader's campaign on a state-by-state basis. Access: http://www.vais.net/ $\sim$ nader96/.

\section{Libertarian Party candidate Harry Browne}

- Harry Browne for President. Official homepage includes statements, articles, interviews, news releases, and endorsements. Access: http://www.HarryBrowne96.org/.

\section{Natural Law Party candidate Jobn Hagelin}

- John Hagelin. Official homepage includes the party platform and action plan, audio clips, news releases, and biographical information about Hagelin and vice-presidential candidate Mike Tompkins. Access: http:// www.hagelin.org/hagelin/

\section{Socialist Party candidate Mary Cal Hollis}

- The Socialist Party Presidential Campaign. The homepage for Hollis includes her biography and press releases. Access: http:// sunsite.unc.edu/spc/prez/index.html

\section{Democratic Party vice-presidential candidate \\ Al Gore}

- Vice President Gore's Homepage. Biography and information about issues on which the vice-president has taken the lead, including National Performance Review, the environment, science, and technology. Access: http:// www. whitehouse.gov/WH/EOP/OVP/html/ GORE_Home.html

\section{Libertarian vice-presidential candidate Jo Jorgensen}

- Jo Jorgensen for Vice President. Biography, press releases, and campaign information aimed specifically at members of Generation X. Access: http://www.harrybrowne96. org/jo/.

\section{Primaries}

- AllPolitics: Primary \& Caucus Dates. A detailed calendar of primary and caucus dates giving number of delegates for both Republican and Democratic parties. Access: http://all politics.com/candidates/calendar/primaries. shtml.

- Countdown '96: Primaries and Caucuses. Links to 1996 primary and caucus results, primaries and caucuses by date and state, and individual primaries. Access: http://www. comeback.com/countdown/primary.html.

- Cybercaucus: Iowa's First-in-the-Nation Caucus. This site includes a history of the Iowa caucus from 1846 to the present, a list of past election outcomes, and information on this year's caucus, with related stories from the Des Moines Register. Access: http://www.drake.edu/ public/caucus.html.

- Nerd World: USA Primaries. A list of links related to primaries, arranged by candidate. Access: http://www nerdworld.com/cgibin/page.cgi?USA_PRIMARIES/600

- University of New Hampshire: NHPrimary. A comprehensive archive of campaign activities related to the 1996 New Hampshire presidential primary. Features vote totals, candidates, media coverage, issue statements, survey data and analysis, and past primary results. Access: http://unhinfo.unh.edu/unh/acad/ libarts/comm/nhprimary/nhprim.html.

\section{Conventions}

- Chicago '96. Homepage of the host committee for the 1996 Democratic National Con- 
vention. Access: http://www.ci.chi.il.us/Chicago96/.

- Democratic National Party Convention 96. Information about the delegate selection process, past convention history and highlights, the party platform, and links to "a welcome map of web sites" about Chicago. Access: http://www.democrats.org/party/convention/index.html.

\section{- Convention '96 San Diego: 1996 GOP National Convention Information Page.} Covers Bob Dole and former candidates, the issues, and what to see and do in San Diego. Includes links to other GOP and political sites. Access: http://www.GoThere.com/sandiego/ conv_ctr/conv96sd.htm.

\section{State and local elections}

Many news and voter education sites also contain information about upcoming state elections.

- ElectNet. Organized by state, this site provides a summary of the political climate in each state, with links to incumbent officials, candidates and other state political Web sites. ElectNet covers candiclates from governor to sheriff. Access: http://www.el.com/gov/home. htm.

- State and Local Candidates. Links to state and local candidates from the National Political Index. Access: http://www.political index.com/sect9.htm.

\section{News sites}

A number of print and national network news organizations sponsor comprehensive election Web sites. These sites include news and analysis of the candidates, races, and issues. Many have special features such as poll results, online polling, special interest group ratings, etc.

- AllPolitics. Buttons for news, issues, candidates, analysis, games, polls, and states keep users up-to-date with all aspects of the '96 campaign, courtesy of $\mathrm{CNN}$ and Time magazine. A detailed calendar of primary and caucus dates gives the number of delegates for both Republican and Democratic parties. The issues link provides a "Quick Take" summary of the issues, the results of public opinion polls, and links to related stories from Time and CNN. Other unique features include political stories from Lexis-Nexis and the Associated Press, poll results, cartoons, a virtual election, and the current issue of Time. A search feature allows us- ers to keyword search CNN stories and Time articles. Access: http://allpolitics.com/.

- Campaign '96 (CBS). News features, coverage of the campaign trail, results from CBS News polls, issue profiles, and campaign funding data compose the bulk of this site. "Election 101" provides background information on the delegate selection process and campaign financing law. "State-by-State" provides extensive tabular information on primaries, delegates, races, 1992 election results, and a current roster of state officials. Access: http://www. cbsnews.com/campaign96/home/

- Countdown '96 Home Page. Maintained by Essential Presence, an Internet marketing firm, this site strives to be the Internet's most comprehensive resource for information about the 1996 presidential election, from parties and candidates to issues and special-interest groups. As part of its goal to provide a single source that will help voters make an informed voting decision, it provides links to state and local parties, primary and caucus results by date and state, opinion and analysis, election and political news, election games and simulations, political humor, online opinion polls, newsgroups, and voter information and education. Access: http://www.comeback.com/countdown/

- CQ's American Voter '96. Congressional Quarterly's (CQ) Web site is packed with information on national politics and political players, including full-text articles from CQ publications. Unique features include "Rate Your Candidate" and "Rate Your Rep," which allow voters to compare their positions on key issues with those of individual candidates and members of Congress. "On the Job" provides access to congressional votes, speeches, and bills. $A c$ cess: http://voter96.cqalert.com/.

- PoliticsNow. Created by the merger of Election Line and PoliticsUSA, this site draws from the resources of Newsweek, the Washington Post, $\mathrm{ABC}$ News, the National Joumal, and the American Political Network. It includes news coverage and analysis of state and federal elections, campaign finance clata, online polling, and links to candidates' and political advocacy groups' homepages. Special features include the day's Washington Post, the latest Associated Press news, and the current issue of Newsweek. Comprehensive issues information is organized into five sections, including "At a Glance," which presents statistics and, occasionally, a glossary; "Time Line," a chronological review of impor- 
tant events; "Legislation," which summarizes recent bills; and "Presidential Candidates," which presents positions taken by Bill Clinton and Bob Dole on issues. Access: http:// www.politicsnow.com.

- Showdown '96. This graphics-intensive site uses charts and graphs to effectively communicate election information, including delegate counts, primary results, campaign finances, polling results, and state-by-state data. The issues section includes a summary of each issue, the candidates' stands on the issue, interest group ratings, and links to advocacy groups. Access: http://www.iguide.com/ pol_govt/showdown/index.htm.

\section{Voter education groups}

Many voter education organizations are establishing a presence on the Internet. These include well-established names like the League of Women Voters, and new groups such as Project Vote Smart. These are efforts to provicle voters with the information they need to come to an informed judgment before voting.

- League of Women Voters Election '96. Part of the League's efforts to get out the vote, this site provides state-by-state registration information, an update on the success of the National Voter Registration Act, and background on election issues, Access: http://www.lwv.org/ $\sim$ lwvus/elect.html.

- Power the Vote. This site, jointly sponsored by the League of Women Voters and the Ladies' Home Journal, provides up-to-theminute campaign information of special interest to women. Access: http://www.lhj-lwv.com/.

- Vote Smart Web. Project Vote Smart, a nonpartisan voter education organization, maintains this Web site to help citizens and journalists obtain objective information on federal and state candidates. Vote Smart provides extensive information about candidates' backgrounds, voting records, campaign finances, and interest group ratings. Candidates' answers to the group's National Political Awareness Test, designed to determine their positions on important issues, are included and links are provided to other sources on the Internet, including pages for candidates and interest groups. Access: http: //www.vote-smart.org/.

- Voter Information Services. Provides interest group ratings of individual members of Congress as well as their "Contract With America" voting record. Access: http://world.std. $\mathrm{com} / \sim$ voteinfo.

\section{Comprehensive guides to election resources}

- Campaign 96 Online. This "comprehensive guide to online politics" includes links to pages for presidential, congressional, and state candidates, parties, directories, media, nonpartisan election information, advocacy groups, liberal and conservative sites, and sites for government information. Access: http://campaign. 96.com/index.html.

- The Jefferson Project. Links to federal, state, and local incumbents and candidates, as well as party resources, groups on the left and right, issues and activists, and political watchdog organizations. Access: http://www.voxpop. org/jefferson/.

\section{Scholarly discussion lists and electronic conferences}

- CLINTON. Bill Clinton's presidency. Subscribe: LISTSERV@VM.MARIST.EDU.

- DEM-DIGITALS. Maintained by Digitals, a small group of Democratic Party activists, for sharing practical campaign techniques, tools, information, activities, etc. Debate or discussion of issues or personalities is prohibited. Subscribe: listserv@netcom.com.

- DEMOCRATS96. 1996 Democratic campaign. Subscribe: LISTSERV@VM.MARIST.EDU

- Elections-reform. Electoral reform including proportional representation, campaign finance, and media access. Subscribe: majordomo@eskimo.com.

- Election-methods. Details of election reform proposals. Subscribe: majordomo@ igc.apc.org.

- EMILY'S LIST Email Network. A weekly digest of EMILY's List campaign and candidate news, information on women voters, and political news from women on the Hill. Subscribe: majordomo@emilyslist.org.

- INDEPENDENTS96. 1996 Independent campaign. Subscribe: LISTSERV@VM.MARIST. EDU.

- PEROT. H. Ross Perot's presidential campaign. Subscribe: LISTSERV@MARIST.EDU.

- PRES161. 1996 presidential election discussion list. Subscribe: LISTSERV@LISTSERV. uic.edu.

- REPUBLICANS96. About the 1996 Republican campaign. Subscribe: LISTSERV@VM. MARIST.EDU.

- VOICE-L. General election campaign issues and media coverage. Subscribe: LISTSERV@MIZZOU1.MISSOURI.EDU. 


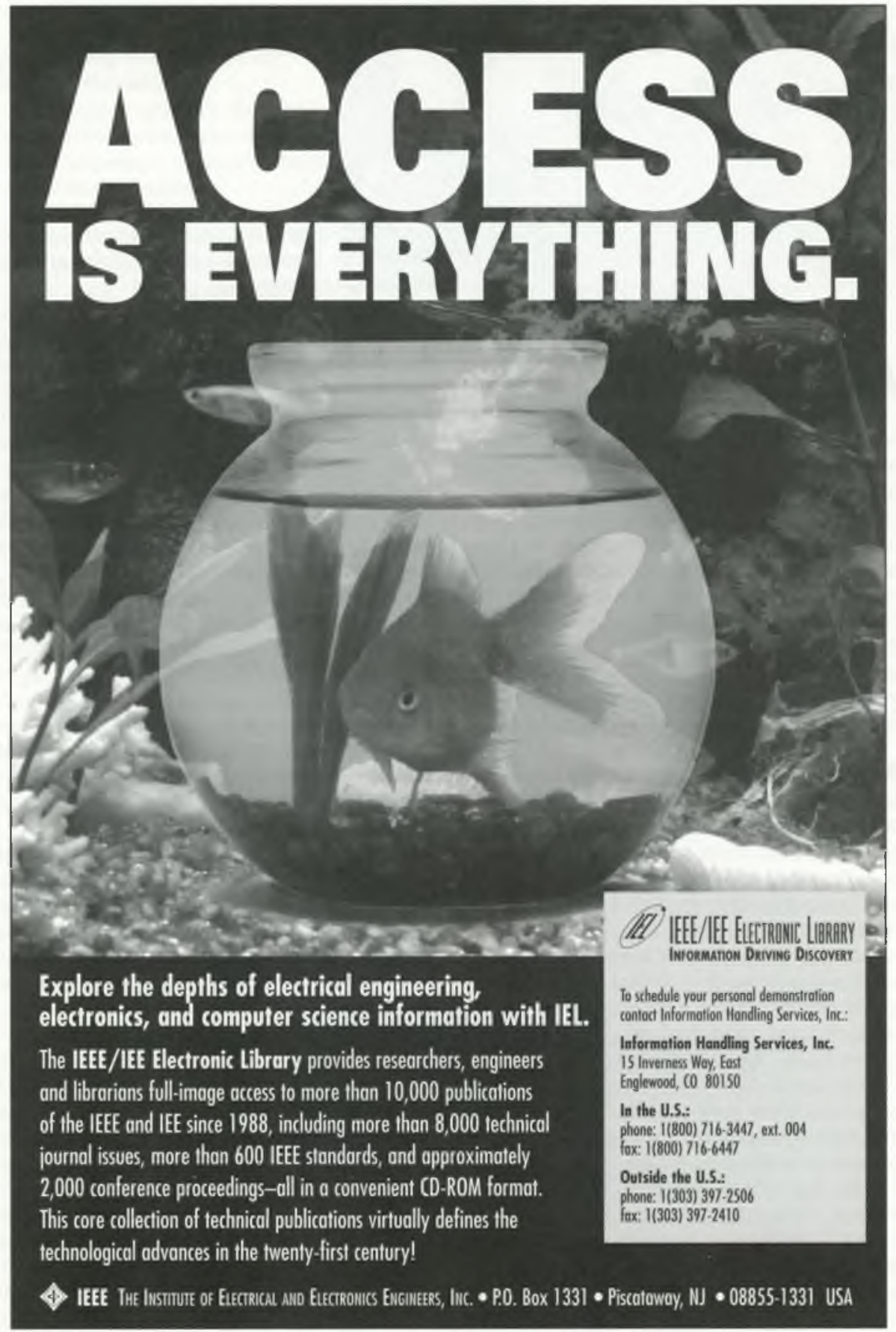

